\title{
Minat Peserta Didik dalam Mengikuti Pembelajaran PJOK pada Masa Pandemi Covid-19
}

\author{
Dian Rahmawati ${ }^{*}$, I Putu Panca Adi ${ }^{2}$, I Ketut Semarayasa ${ }^{3}$ iD
${ }^{123}$ Universitas Pendidikan Ganesha
${ }^{*}$ Corresponding author: dianrahma155@gmail.com
}

PJOK harus tetap diberikan kepada peserta didik meskipun secara online. Namun, pada kenyataannya belum dapat diketahui seberapa besar minat peserta didik dalam mengikuti pembelajaran PJOK. Penelitian ini bertujuan untuk mengetahui Minat Peserta Didik dalam Mengikuti Pembelajaran PJOK pada Masa Pandemi Covid-19. Penelitian ini merupakan penelitian deskriptif kuantitatif dengan metode pengumpulan data survei, sedangkan jenis survei yang digunakan yaitu kuisioner yang dijawab oleh peserta didik. Populasi dalam penelitian ini adalah 338 orang. Sampel penelitian dipilih berdasarkan convenience sampling yang ini diambil $25 \%$ dari total populasi yaitu sebanyak 85 orang. Analisis data yang digunakan dalam penelitian ini menggunakan statistik deskriptif kuantitatif kemudian dikategorikan berdasarkan skala penilaian. Hasil penelitian ini antara lain, pada faktor intrinsik minat peserta didik dalam mengikuti pembelajaran PJOK pada masa pandemi covid-19 mendapatkan skor $78 \%$, dimana pada skala penilaian kategori angka tersebut dinyatakan dengan tinggi. Hasil penelitian pada faktor ekstrinsik minat peserta didik dalam mengikuti pembelajaran PJOK pada masa pandemi covid-19 mendapatkan skor 71,9\% dimana pada skala penilaian kategori, angka tersebut dinyatakan tinggi. Kedua skor dari indikator variabel minat peserta didik apabila dirata-ratakan mendapatkan skor yaitu 74,9\%. Angka tersebut jika disesuaikan dengan skala penilaian kategori termasuk dalam kategori tinggi, dengan demikian peneliti menyarankan kepada peserta didik agar mempertahankan minatnya dalam mengikuti pembelajaran PJOK pada masa pandemi covid-19.

Kata-kata kunci: Minat, Pembelajaran PJOK, Pandemi Covid-19

\section{Abstract}

PJOK must still be given to students even though it is online. However, it is not yet known how much interest students have in participating in PJOK learning. This study aims to determine the interest of students in participating in PJOK learning during the Covid-19 pandemic. This research is a quantitative descriptive study with survey data collection methods, while the type of survey used is a questionnaire answered by students. The population in this study were 338 people. The research sample was selected based on convenience sampling, which took $25 \%$ of the total population, namely 85 people. The data used in this study used quantitative descriptive statistics and then categorized based on the rating scale. The results of this study include, among other things, the intrinsic factor of students' interest in participating in PJOK learning during the covid-19 pandemic, getting a score of $78 \%$, where on the category rating scale, the number is stated as high. The study's results on the irrelevant factor of students' interest in participating in PJOK learning during the covid-19 pandemic got a score of $71.9 \%$ were on the category rating scale. The two scores of the variable indicators of student interest, if averaged, get a score of $74.9 \%$. If this figure is adjusted to the category rating scale, it is included in the high category. Thus the researcher advises students to maintain their interest in participating in PJOK learning during the COVID-19 pandemic.

Keywords: Interests, Learning PJOK, Covid-19 Pandemic

$\begin{array}{ll}\text { History: } & \text { Publisher: Undiksha Press } \\ \text { Received: } 15 \text { April } 2020 & \text { Licensed: This work is licensed under } \\ \text { Revised: 10 May 2020 } & \text { a Creative Commons Attribution 3.0 License } \\ \text { Accepted: 01 Juni 2020 } & \text { C) } \\ \text { Published: 29 Juni } 2020 & \end{array}$




\section{Pendahuluan}

Indonesia sedang dilanda sebuah musibah dengan masuknya sebuah virus yang mampu membuat seluruh masyarakat panik yaitu virus corona atau covid-19. (Arum, 2020) Virus corona telah terjangkit cukup masif di dunia sehingga status virus corona dikatakan sebagai pandemi (Kresna, 2020). Pandemi covid-19 tidak hanya berdampak pada kondisi perekonomian suatu negara, menghambat interaksi sosial di kalangan masyarakat, serta juga memiliki dampak terhadap kondisi kesehatan setiap manusia. Adanya Covid-19 mengakibatkan beberapa daerah di sebuah Negara menerapkan berbagai kebijakan demi menekan angka penambahan pasien covid-19 termasuk social distancing. yang mengharuskan masyarakat untuk bekerja dan sekolah dari rumah. Peraturan tersebut diberikan pemerintah lantaran setiap individu memiliki kemungkinan terjangkit virus covid19 (Kresna, 2020). Pemerintah Negara Indonesia telah mengambil kebijakan dengan pembatasan sosial (social distancing) dan pembahasan kontak fisik (physical distancing) berupa tinggal dirumah, bekerja dirumah, belajar dan beribadah di rumah. PJOK menjadi salah satu solusi untuk menjaga masyarakat khususnya di kalangan peserta didik agar tetap sehat dan bugar sehingga dapat terhindar dari covid-19 serta beberapa penyakit lainnya. Melihat hal tersebut PJOK harus tetap diberikan kepada peserta didik meskipun secara online.

Minat dapat dikatakan sebagai ketertarikan seseorang terhadap suatu hal dengan tujuan tertentu. Syah (Budiwibowo, 2016) Minat adalah kecenderungan dan kegairahan yang tinggi atau keinginan yang besar terhadap sesuatu. Minat adalah suatu rasa lebih suka dan rasa ketertarikan pada suatu hal atau aktivitas tanpa ada yang menyuruh (Slameto, 2015). Setiap individu mempunyai keinginan untuk berhubungan dengan sesuatu yang ada di sekitar lingkungannya baik itu tentang suatu hal maupun aktivitas. Sedangkan (Djali, 2007), menyatakan bahwa minat yang besar (keinginan yang kuat) terhadap sesuatu merupakan modal besar untuk mencapai tujuan. Berdasarkan pemaparan para ahli, dapat disimpulkan bahwa minat adalah keinginan atau ketertarikan seseorang terhadap sesuatu hal tanpa adanya paksaan dari orang lain, melainkan karena adanya tujuan tertentu. Besar kecilnya minat seseorang mempengaruhi pencapaian tujuan.

Terdapat beberapa hal yang dapat dikatakan menjadi sebuah indikator dari adanya minat. Safari (Budiwibowo, 2016) terdapat beberapa indikator yang mempengaruhi minat belajar peserta didik yaitu rasa tertarik, perasaan senang, perhatian, partisipasi dan keinginan atau kesadaran. Seseorang dikatakan memiliki minat terhadap sesuatu, apabila ia mempunyai perasaan senang, perasaan tertarik dan penuh perhatian (Kartini, 2007). Beberapa indikator minat belajar yaitu sebagai berikut (1) Perasaan senang, (2) Ketertarikan siswa, (3) Perhatian dan (4) Keterlibatan siswa Safari (dalam Wasti, 2013). Maka dapat disimpulkan bahwa indikator dari minat dibagi menjadi dua yaitu faktor intrinsik dan faktor ekstrinsik. Faktor intrinsik memiliki indikator antara lain kebutuhan, pengalaman, rasa tertarik, rasa senang dan rasa perhatian.Sedangkan faktor ekstrinsik memiliki indikator yaitu alat dan fasilitas, aktivitas dan guru.

Pandemi covid-19 telah menjadi sebuah pandemi. Pembelajaran PJOK dapat membantu masyarakat khususnya dikalangan peserta didik dari penyebarluasan virus ini. "Pembelajaran ialah membelajarkan siswa menggunakan asas pendidikan maupun teori belajar merupakan penentu utamakeberhasilan pendidikan"(Sagala, 2014). Dimyati dan Mudjiono (Sagala, 2014) pembelajaran adalah kegiatan guru secara terprogram dalam desain instruksional, untuk membuat siswa belajar secara aktif, yang menekankan pada penyediaan sumber belajar. UUSPN No. 20 tahun 2003 (Sagala, 2014) pembelajaran adalah proses interaksi peserta didik dengan pendidik dan sumber belajar pada suatu lingkungan belajar. Pendidikan Jasmani Olahraga dan Kesehatan pada hakikatnya adalah proses pendidikan yang 
memanfaatkan aktivitas fisik (jasmani) dan olahraga untuk menghasilkan perubahan holistik dalam kualitas individu baik dalam hal fisik, mental serta emosional (Paturisi, 2012).

Berdasarkan pernyataan diatas yang dimaksud dengan pembelajaran dalam PJOK adalah proses interaksi antara peserta didik dengan pendidik dan sumber belajar pada suatu lingkungan belajar dengan kegiatan yang telah dirancang guru untuk membuat peserta didik aktif dan mendapatkan perubahan holistik dalam kualitas individu secara fisik, mental dan emosional melalui aktivitas gerak.

Pada masa pandemi covid-19 pembelajaran daring atau pembelajaran dalam jaringan menjadi solusi utama bagi dunia pendidikan. Kunarto (Yanti, Minanti Tirta., 2020) Model pembelajaran daring merupakan pembelajaran yang memanfaatkan teknologi multimedia, video, kelas virtual, teks online animasi, pesan suara, email, telepon konferensi, dan video streaming online. Sistem pembelajaran modern berbasis teknologi informasi memberikan kualitas luasnya jangkauan yang sangat cocok untuk masyarakat milineal yang dapat diakses di berbagai tempat dan waktu (Mustofa, 2019). Salah satu teknologi informasi yang ikut berperan dalam dunia pendidikan adalah pembelajaran daring (Sofyana, 2019).

Pembelajaran daring bisa dijalankan berkat adanya internet. Arishanti dan Subhan (2018) Internet adalah suatu jaringan informasi berbagai komputer yang terhubung dan berkommunikasi satu sama lain yang digunakan sebagai sumber dan media dari berbagai pengetahuan. Pembelajaran daring Learning memperluas komunitas pembelajaran(Sobron, A.N., 2019). Artinya dibandingkan diskusi tatap muka, melalui pembelajaran daring peserta didik dapat berkomunikasi lebih baik tanpa adanya batas ruang dan waktu.

Berdasarkan pemaparan diatas dapat disimpulkan bahwa pembelajaran daring adalah Sistem pembelajaran modern berbasis teknologi informasi berupa multimedia, video, kelas virtual, teks online animasi, pesan suara, email, telepon konferensi, dan video streaming online dengan bantuan jaringan internet yang digunakan sebagai penghubung antara pendidik dengan peserta didik yang dapat diakses tanpa batasan ruang dan waktu.

Pandemi adalah sebuah istilah yang digunakan ketika suatu wabah atau virus telah menyebar secara global (Arum, 2020). Covid-19 merupakan penyakit menular yang berpotensi menimbulkan kedaruratan kesehatan masyarakat (Telaumbanua, 2020). Pandemi Covid-19 adalah bencana tidak alami yang dapat berdampak pada kesehatan mental dan kondisi psikososial setiap orang (Pragholapati, 2020). Masyarakat diharapkan agar tetap mengikuti anjuran pemerintah dengan menaati semua kebijakan sosial distancing atau dikenal pula physical distancing (untuk menjaga jarak fisik), dilakukan sebagai upaya untuk meminimalisir dan mencegah penyebaran virus Covid-19.

Namun, pada kenyataannya belum dapat diketahui seberapa besar minat peserta didik dalam mengikuti pembelajaran PJOK di kelas XI SMK Negeri 2 Negara Berdasarkan uraian di atas peneliti tertarik untuk melakukan penelitian dengan judul "Minat Peserta Didik dalam Mengikuti Pembelajaran PJOK pada Masa Pandemi Covid-19 di Kelas XI SMK Negeri 2 Negara”.

\section{Metode}

Penelitian ini termasuk kedalam jenis penelitian deskriptif dengan pendekatan kuantitatif. Metode yang digunakan dalam pengumpulan data penelitian ini menggunakan metode survei, sedangkan jenis survei yang digunakan yaitu survei kuisioner yang dijawab oleh peserta didik. Populasi dalam penelitian ini adalah seluruh peserta didik kelas XI SMK Negeri 2 Negara, dengan jumlah 338 orang. Sementara sampel dipilih berdasarkan convenience sampling yang ini diambil $25 \%$ dari populasi penelitian, dimana total sampelnya adalah sebanyak 85 orang.

Berdasarkan pemaparan diatas, pengumpulan data dalam penelitian ini menggunakan kuisioner, dimana kuisioner yang disebarkan terdapat 20 pernyataan yang terdiri dari 16 
pernyataan positif dan 4 pernyataan negatif. Jawaban peserta didik diklasifikasikan yaitu sangat setuju (SS), Setuju (S), Tidak Setuju (TS) dan Sangat Tidak Setuju (STS).

\section{Hasil dan Pembahasan \\ Hasil Penelitian}

Hasil analisis minat peserta didik dalam mengikuti pembelajaran PJOK pada masa pandemi covid-19 tersaji pada tabel berikut ini.

Tabel 1. Hasil Analisis Deskriptif

\begin{tabular}{ccccc}
\hline No. & Indikator & Banyak siswa & Rata-rata & Katagori \\
\hline 1. & Faktor Instrinsik & 85 & 78 & Tinggi \\
\hline 2. & Faktor Ekstrinsik & 85 & 71,9 & Tinggi \\
\hline
\end{tabular}

20 Pernyataan pada indikator intrinsik memperoleh skor $78 \%$, sedanglan pada 20 pernyataan indikator ekstrinsik mendapatkan skor 71,9\%. Angka tersebut bila dikonversikan dalam tabel skala penilaian kategori berada pada kategori tinggi, untuk mengetahui hasil analisis data pada kedua indikator pada variabel minat peserta didik dalam mengikuti pembelajaran PJOK pada masa pandemi covid-19 maka rumus yang digunakan yaitu:

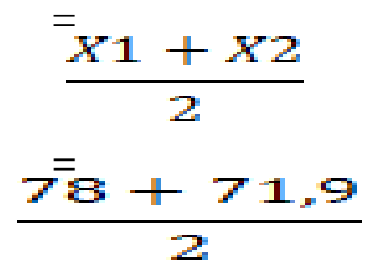

$=74,9$

Angka tersebut apabila dilihat pada skala penilaian kategori terrgolong pada kategori tinggi.

\section{Simpulan}

Berdasarkan hasil analisis data yang menggunakan deskriptif kuantitatif, maka dapat disimpulkan bahwa Minat Peserta Didik dalam Mengikuti Pembelajaran PJOK pada Masa Pandemi Covid-19 di Kelas XI SMK Negeri 2 Negara adalah tinggi.

Berdasarkan simpulan penelitian tersebut, adapun saran yang dapat diberikan adalah sebagai berikut: 1. Bagi peserta didik, peserta didik diharapkan untuk mempertahankan minatnya yang sudah tinggi dalam mengikuti pembelajaran PJOK pada masa pandemi covid19, dengan harapan melalui aktivitas gerak yang ada dalam pembelajaran PJOK, kesehatan peserta didik tetap terjaga dan terhindar dari penularan covid-19 dengan meningkatkan daya tahan tubuh, 2. Bagi peneliti, bagi peneliti lain yang berminat mengadakan penelitian deskriptif kuantitatif tentang survei minat peserta didik dalam mengikuti pembelajaran PJOK pada masa pandemi covid-19, agar menjadikan hasil penelitian ini sebagai salah satu referensi untuk meneliti dalam lingkup yang lebih luas, sehingga diperoleh sumbangan ilmu yang lebih baik dan sesuai dengan perkembangan zaman dan diperoleh dalam penelitian lebih objektif, 3. Bagi Guru, guru diharapkan untuk lebih memperhatikan lagi cara agar dapat mempertahankan minat peserta didik yang tergolong sangat baik dalam mengikuti pembelajaran PJOK pada masa pandemi covid-19.. 


\section{Daftar Pustaka}

Arum, R. (2020). Pembatasan Sosial di Indonesia Akibat Virus Corona Ditinjau dari Sudut Pandang Politik. Retrieved from https://osf.io/preprints/lawarxiv/g8ny3

Budiwibowo, S. (2016). Hubungan Minat Belajar Siswa dengan Hasil Belajar IPS di SMP Negeri 14 Kota Madiun. Retrieved from http:/ejournal.unipma.ac.id/index.php/gulawentah/article/view/66.

Djali. (2007). Psikologi Pendidikan. Jakarta: PT Bumi Aksara.

Kartini, T. (2007). Penggunaan Metode Role Playing untuk Meningkatkan Minat Siswa dalam Pembelajaran Pengetahuan Sosial di Kelas V SDN Cileuyi I Kecamatan Cileuyi Kabupaten Bandung. Retrieved from http://file.upi.edu/Direktori/JURNAL/PENDIDIKAN_DASAR/Nomor_8Oktober_2007/ Penggunaan_Metode_Role_Playing_untuk_Meningkatkan_Minat_Siswa_dalam_Pembe lajaran_Pengetahuan_Sosial_di_Kelas_V_SDN_Cileunyi_I_Kecamatan_Cileunyi_Kabu paten_Bandung.pdf.

Kresna, A. dan J. A. (2020). Pengaruh Physical Distancing dan Social Distancing terhadap Kesehatan dalam Pendekatan Linguistik. Retrieved from https://jurnal.syntaxtransformation.co.id/index.php/jst/article/view/42

Mustofa, I. M. dkk. (2019). Formulasi Model Perkuliahan Daring Sebagai Upaya Menekan Disparitas Kualitas Perguruan Tinggi. Retrieved from https://www.journal.walisongo.ac.id/index.php/jit/article/view/4067

Paturisi, A. (2012). Management Pendidikan Jasmani dan Olahraga. Jakarta: PT. Rineka Cipta.

Pragholapati, A. (2020). Covid-19 Impact on Students. Retrieved from https://edarxiv.org/895ed

Sagala, S. (2014). Konsep dan Makna Pembelajaran untuk Membantu Memecahkan Problematika Belajar dan Mengajar. Bandung: Alfabeta.

Slameto. (2015). Metodelogi Penelitian \& Inovasi Pendidikan. Salatiga: Cipta.

Sobron, A.N., D. (2019). Persepsi Siswa dalam Studi Pengaruh Daring Learning Terhadap Minat Belajar IPA. Retrieved from https://ejournal.insuriponorogo.ac.id/index.php/scaffolding/article/view/117

Sofyana, L. dan A. R. (2019). Pembelajaran Daring Kombinasi Berbasis Whatsapp pada Kelas Karyawan Prodi Teknik Informatika Universitas PGRI Madiun. Retrieved from https://ejournal.undiksha.ac.id/index.php/janapati/article/view/17204

Telaumbanua, D. (2020). Urgensi Pembentukan Aturan Terkait Pencegahan Covid-19. Retrieved

from https://ejournal.insuriponogoro.ac.id/index.php/qalamuna/article/view/290

Yanti, Minanti Tirta., D. (2020). Pemanfaatan Portal Rumah Belajar Kemendikbud Sebagai Model Pembelajaran Daring di Sekolah Dasar. Retrieved from http://ejournal.ihdn.ac.id/index.php/AW/article/view/1306 